\title{
SKUTKI NIEDOPEŁNIENIA OBOWIĄZKU NASADZEŃ ZASTĘPCZYCH
}

\section{CONSEQUENCES OF OMISSION OF REPLACEMENT PLANTING OBLIGATION}

\section{STRESZCZENIE}

Nasadzenia zastępcze stanowią istotny element modelu powszechnej ochrony przyrody realizowanej poprzez mechanizm administracyjnoprawnej reglamentacji usuwania drzew i krzewów. Podstawową instytucją tego modelu jest zezwolenie na usunięcie drzewa lub krzewu. Zezwolenie to może przybrać postać zezwolenia prostego, w którym rozstrzygnięcie ogranicza się wyłącznie do oświadczenia o wyrażeniu zgody na usunięcie drzewa lub krzewu bądź też zezwolenia złożonego, gdzie z przyznanym uprawnieniem skorelowany zostaje obowiązek uiszczenia opłaty lub/i obowiązek dokonania nasadzeń

Doktor nauk prawnych, adiunkt w Katedrze Prawa Ochrony Środowiska; Wydział Prawa i Administracji Uniwersytetu Mikołaja Kopernika. 
zastępczych. Analiza przepisów Ustawy o ochronie przyrody pozwala przyjąć, iż ustawodawca nie określił na gruncie tej regulacji prawnej szczególnych reguł wygaśnięcia obowiązku nasadzeń zastępczych, co z kolei prowadzi do wniosku, że obowiązek ten wygasa, zgodnie z zasadą, wyłącznie poprzez jego wykonanie. Oznacza to, iż podstawowym skutkiem niedopełnienia (wynikającego z zezwolenia na usunięcie drzew i krzewów) obowiązku nasadzeń zastępczych jest uruchomienie kompetencji organów administracji publicznej do podjęcia przewidzianych prawem środków prawnych gwarantujących wykonanie aktu administracyjnego, w tym w szczególności środków egzekucyjnych.

\section{Słowa kluczowe}

Ochrona przyrody; usunięcie drzewa lub krzewu; nasadzenie zastępcze drzewa lub krzewu; środek egzekucyjny.

\section{ABSTRACT}

The obligation to plant replacement trees or shrubs forms an important element of the general nature conservation model based on the administrative restrictions concerning trees and shrubs removal. A permit to remove trees or shrubs is a primary legal instrument of this model. There are two types of such a permit. A basic permit only encompasses the statement of approval for trees or shrubs removal. Combined permit consists of such an approval in conjunction with the obligation to pay a fee or/and the obligation to plant replacement tree or shrub. The analysis of the Nature Conservation Act leads to a conclusion that the Polish legislator does not prescribe any detailed regulations for the expiration of the obligation to plant replacement trees or shrubs. Consequently, such an obligation expires solely by its execution. Therefore, an elementary consequence of the omission of the obligation to plant replacement trees or shrubs is the possibility of exertion of legal means by public authorities allowing the realization of the administrative act, especially of enforcement measures.

\section{Keywords}

Nature conservation; trees or shrubs removal; replacement planting obligation; enforcement measure. 


\section{ZAGADNIENIA WPROWADZAJĄCE}

Jedną z podstawowych instytucji powszechnej ochrony przyrody jest ochrona drzew i krzewów poza lasami ${ }^{1}$, realizowana poprzez mechanizm administracyjnoprawnej reglamentacji ich usuwania opartej o model zezwolenia administracyjnego. Zezwolenie to stanowi instytucję materialnego prawa administracyjnego, polegającą na podejmowaniu przez organy władzy publicznej czynności umożliwiających jednostce przejawianie określonych zachowań, bez których zachowania takie byłyby prawnie niedopuszczalne ${ }^{2}$. Jak słusznie zauważa D. Kijowski, zezwolenia stanowią specyficzny instrument prawa administracyjnego materialnego, pozwalający nie tylko na oświadczenie woli organu władzy wykonawczej, że nie istnieją podstawy do uznania zamierzonej czynności lub działalności za niedopuszczalną ze względu na wartości, dobra podlegające ochronie prawnej (czyli na zrealizowanie ich funkcji ochronnej, w ramach swoistego prewencyjnego nadzoru policyjnego), ale ponadto umożliwiający określenie treści uprawnień i obowiązków ich posiadacza w trakcie korzystania z uzyskanego uprawnienia administracyjnego (funkcja regulacyjna), a nawet stymulowanie go do podejmowania zachowań korzystnych z punktu widzenia interesu publicznego (funkcja sterująca zezwolenia) ${ }^{3}$. Szczególnie istotne dla tak postrzeganej funkcji zezwolenia jest wyposażenie organów administracji publicznej w kompetencje do kreowania sytuacji prawnej adresata zezwolenia, opartej na współzależności przyznanych zezwoleniem uprawnień oraz określonych w nim zindywidualizowanych obowiązków. Wpisującą się $w$ ten model kompetencji organów administracyjnych instytucją ochrony zadrzewień $\mathrm{w}$ prawie polskim jest instytu-

1 Por. A. Habuda, W. Radecki, Instytucje prawa ochrony przyrody, w: Instytucje prawa ochrony środowiska. Geneza-rozwój-perspektywy, red. W. Radecki, Warszawa 2010, s. 209.

2 D. R. Kijowski, Uprawnienia administracyjne, w: Prawo administracyjne materialne, t. 7, System prawa administracyjnego, red. R. Hauser, Z. Niewiadomski, A. Wróbel, Warszawa 2012, s. 384.

3 Ibidem, s. 388. 
cja nasadzeń zastępczych. Obowiązek dokonania nasadzeń zastępczych jest obowiązkiem subsydiarnym względem uprawnienia do dokonania usunięcia drzewa lub krzewu. Zgodnie z art. 83b ust. 1 pkt 9a u.o.p. ${ }^{4}$ nasadzenia zastępcze stanowią kompensację przyrodniczą w rozumieniu art. 3 pkt 8 u.p.o.ś. ${ }^{5}$, czyli zespół działań prowadzących do przywrócenia równowagi przyrodniczej lub tworzenie skupień roślinności, prowadzących do przywrócenia równowagi przyrodniczej na danym terenie, wyrównania szkód dokonanych w środowisku przez realizację przedsięwzięcia i zachowanie walorów krajobrazowych. O obowiązku dokonania nasadzeń zastępczych orzeka organ wydający zezwolenie na usunięcie drzewa lub krzewu, biorąc pod uwagę w szczególności dostępność miejsc do nasadzeń zastępczych oraz następujące cechy usuwanego drzewa lub krzewu: 1) wartość przyrodniczą, w tym rozmiar drzewa lub powierzchnię krzewów oraz funkcje, jakie pełnią w ekosystemie, 2) wartość kulturową, 3) walory krajobrazowe, 4) lokalizację.

Analiza istoty obowiązku nasadzeń zastępczych w kontekście konstrukcji aktu administracyjnego prowadzi do wniosku, iż rozstrzygnięcie w przedmiocie nasadzeń zastępczych, stanowiące element zezwolenia na usunięcie drzewa lub krzewu, nie jest w swej istocie warunkiem udzielonego zezwolenia, lecz odpowiada koncepcji zlecenia. Wykonanie (niewykonanie) zlecenia nie wpływa bezpośrednio na obowiązywanie aktu administracyjnego czy też jego skuteczność, ale stanowi źródło obowiązku pozostającego $\mathrm{w}$ bezpośrednim związku z jego zasadniczą treścią (rozstrzygnięciem). Istoty obowiązku nasadzeń zastępczych należy upatrywać we władczej wypowiedzi organu administracji publicznej zezwalającej na usunięcie konkretnie wskazanego elementu przyrodniczego z zastrzeżeniem zrekompensowania zaistniałego uszczerbku poprzez posadzenie innych drzew i krzewów na zasadach określonych w zezwoleniu.

4 Ustawa z dnia 16 kwietnia 2004 r. o ochronie przyrody, t.j. Dz.U. z 2015 r., poz. 1651 ze zm., zwana dalej Ustawą o ochronie przyrody lub określana skrótem u.o.p.

5 Ustawa z dnia 27 kwietnia 2001 r. Prawo ochrony środowiska, t.j. Dz.U. z 2013 r., poz. 1232 ze zm., określana skrótem u.p.o.ś. 
W świetle powyższych ustaleń pojawia się pytanie o skutki niedopełnienia obowiązku nasadzeń zastępczych oraz związany z tym stanem zakres kompetencji organów administracji publicznej.

Dotychczas w doktrynie prawa ochrony środowiska dominował, wynikający z faktu ujmowania obowiązku nasadzeń zastępczych jako warunku zezwolenia na usunięcie drzew czy krzewów, pogląd, iż skutkiem niedopełnienia obowiązku nasadzeń zastępczych jest wygaśnięcie zezwolenia ${ }^{6} \mathrm{w}$ związku z art. $162 \S 1$ pkt 2 k.p.a. ${ }^{7}$ Odrzucenie koncepcji warunku jako konstrukcji normatywnej obowiązku nasadzeń zastępczych $\mathrm{w}$ relacji do uprawnienia wynikającego z zezwolenia na usunięcie drzew lub krzewów wyklucza możliwość odwołania się do treści art. $162 \S 1$ pkt 2 k.p.a. oraz upatrywania w niedopełnieniu obowiązku nasadzeń zastępczych przyczyny wygaśnięcia zezwolenia. Podstawowe znaczenie dla ustalenia skutków niedopełnienia obowiązku nasadzeń zastępczych mają przepisy Ustawy o ochronie przyrody oraz przepisy kodeksu postępowania administracyjnego, a także ogólne zasady prawa i postępowania administracyjnego.

\section{NASADZENIA ZASTĘPCZE A OBOWIĄZEK UISZCZENIA OPŁATY ZA USUNIĘCIE DRZEW I KRZEWÓW}

Zasadą przyjętą na gruncie Ustawy o ochronie przyrody jest odpłatność za usuwanie drzew czy krzewów. Zgodnie z art.

6 B. Rakoczy, Usuwanie drzew i krzewów, Warszawa 2013, s. 73 i n.; G. Klimek, Nasadzenia zastępcze - wybrane problemy w podejmowaniu decyzji, w: Prawne aspekty gospodarowania zasobami środowiska. Korzystanie z zasobów środowiska, red. B. Rakoczy, M. Szalewska, K. Karpus, Toruń 2014, s. 211 i n.; W. Radecki, Nasadzenia zastępcze przy usuwaniu drzew bez konieczności ponoszenia opłat, „Nowe Zeszyty Samorządowe” 2006, nr 2, s. 56 i n.; K. Gruszecki, Realizacja zasady zrównoważonego rozwoju środowiska („nasadzenia zastępcze"), ZNSA 2007, nr 5-6, s. 37 i n.

7 Ustawa z dnia 14 czerwca 1960 r. Kodeks postępowania administracyjnego, t.j. Dz.U. z 2013 r., poz. 267 ze zm. (określana dalej k.p.a.). 
84 ust. 1 u.o.p. posiadacz nieruchomości ponosi opłatę za usunięcie drzewa lub krzewu. W doktrynie prawa ochrony środowiska przyjmuje się, iż opłata za usuwanie drzew i krzewów stanowi opłatę za korzystanie ze środowiska ${ }^{8}$, pełniącą funkcję stymulującą oraz kompensacyjną ${ }^{9}$. Jednocześnie ustawodawca w art. 86 ust. 1 u.o.p. zawarł obszerny katalog zwolnień z obowiązku uiszczenia opłaty. Zwolnienia te odnoszą się zarówno do kryteriów podmiotowych (zwolnienie z obowiązku uiszczenia opłaty za usunięcie drzew lub krzewów, na których usunięcie osoba fizyczna uzyskała zezwolenie na cele niezwiązane z prowadzeniem działalności gospodarczej), jak też przedmiotowych (np. obwód pnia, cel usunięcia) ${ }^{10}$. Oznacza to, że w przypadku zwolnień przedmiotowych (art. 86 ust. 1 pkt 1, 3-15 u.o.p.) zwolnieniem tym objęci zostaną wszyscy wnioskodawcy niezależnie od ich statusu prawnego (osoby fizyczne, osoby prawne, jednostki organizacyjne nieposiadające osobowości prawnej). Zwolnienie podmiotowe odnosi się wyłącznie od osób fizycznych w momencie, gdy usunięcie drzewa lub krzewu nie jest dokonywane na cele związane z prowadzeniem działalności gospodarczej. Niezależnie od ustawowo określonego obowiązku opłatowego ustawodawca wyposażył organ orzekający w sprawie udzielenia zezwolenia w kompetencje do nakładania obowiązku dokonania nasadzeń zastępczych. Wykładnia językowa Ustawy o ochronie przyrody wyklucza tezę jakoby obowiązek nasadzeń zastępczych mógł być nakładany wyłącznie w powiązaniu z obowiązkiem uiszczenia opłaty. Oznacza to, że obowiązek ten może zostać zawarty zarówno w zezwoleniu, w którym ustalona została jednocześnie opłata za usunięcie drzewa lub krzewu, jak i w zezwoleniu, gdzie opłata ta nie została ustalona w związku z treścią art. 86 ust. 1 u.o.p. Ustawodawca określił jednocześnie expressis verbis skutki, jakie dla obowiązku opła-

8 W. Radecki, Rozliczanie opłat za usuwanie drzew, „Nowe Zeszyty Samorządowe" 2010, nr 1, s. 37.

9 B. Rakoczy, op. cit., s. 82; J. Rotko, w: Teoretyczne podstawy prawa ochrony przyrody, red. W. Radecki, Wrocław 2006, s. 217.

10 Por. K. Gruszecki, Zezwolenia na usunięcie drzew i krzewów, LEX/el 2010. 
towego ma z jednej strony samo nałożenie na adresata decyzji obowiązku nasadzeń zastępczych, z drugiej - jego wykonanie. Zgodnie $\mathrm{z}$ art. 84 ust. 3 u.o.p. w przypadku naliczenia opłaty za usunięcie drzewa lub krzewu oraz uzależnienia wydania zezwolenia na usunięcie drzewa lub krzewu od wykonania nasadzeń zastępczych organ właściwy do wydania zezwolenia odracza termin uiszczenia opłaty za jego usunięcie na okres 3 lat od dnia upływu terminu wskazanego w zezwoleniu na wykonanie nasadzeń zastępczych. Odroczenie to ma charakter obligatoryjny. Organ orzekający w sprawie związany jest również ustawowym terminem odroczenia. Na skutek odroczenia terminu płatności opłata stanowi należność niewymagalną. Instytucja odroczenia terminu płatności opłaty z tytułu usunięcia drzewa lub krzewu pozostaje w ścisłym związku z realizacją obowiązku dokonania nasadzeń zastępczych jako przesłanki umorzenia nałożonej opłaty. Zgodnie $\mathrm{z}$ art. 83d ust. 2 u.o.p. w momencie uzależnienia wydania zezwolenia na usunięcie drzewa lub krzewu od wykonania nasadzeń zastępczych zezwolenie to określa dodatkowo: 1) miejsce nasadzeń, 2) liczbę drzew lub wielkość powierzchni krzewów, 3) minimalny obwód pni drzew na wysokości $100 \mathrm{~cm}$ lub minimalny wiek krzewów, 4) gatunek lub odmianę drzew lub krzewów, 5) termin wykonania nasadzeń, 6) termin złożenia informacji o wykonaniu nasadzeń. Wskazane elementy zezwolenia konkretyzują treść obowiązku nasadzeń zastępczych zarówno co do materiału nasadzeniowego, jak i warunków wykonania obowiązku (miejsce, termin). Ponadto organ może określić w zezwoleniu dodatkowe warunki techniczne sadzenia drzew. Wykonanie obowiązku nasadzeń zastępczych zgodnie $\mathrm{z}$ udzielonym zezwoleniem stanowi podstawę umorzenia opłaty ustalonej w zezwoleniu na usunięcie drzewa lub krzewu. Przepis art. 84 ust. 4 u.o.p. stanowi, że jeżeli posadzone drzewa lub krzewy zachowały żywotność po upływie okresu, o którym mowa w art. 84 ust. 3 u.o.p. lub nie zachowały żywotności z przyczyn niezależnych od posiadacza nieruchomości, należność z tytułu ustalonej opłaty za usunięcie drzew lub krzewów podlega umorzeniu. Oznacza to, iż przesłanką umorzenia należności z tytułu opłaty za usunięcie drzewa lub krzewu jest: 
- wykonanie obowiązku nasadzeń zastępczych zgodnie $\mathrm{z}$ udzielonym zezwoleniem;

- zachowanie żywotności ${ }^{11}$ posadzonych drzew lub krzewów po upływie 3 lat od ustalonego w zezwoleniu terminu przesadzenia lub niezachowanie $\mathrm{w}$ tym terminie żywotności z przyczyn niezależnych od posiadacza nieruchomości.

W przypadku ziszczenia się określonych powyżej warunków organ, który wydał zezwolenie, ma obowiązek umorzyć ustaloną w zezwoleniu opłatę w drodze odrębnej decyzji administracyjnej. Ustawa o ochronie przyrody, w brzmieniu obowiązującym od dnia 28 sierpnia 2015 r. $^{12}$, w sposób szczegółowy określa skutki w zakresie obowiązku opłatowego, wynikające z niedopełnienia lub częściowego niedopełnienia obowiązku nasadzeń zastępczych lub niezachowania żywotności przesadzonych drzew lub krzewów. Ustawodawca nakłada bowiem na organ administracji publicznej, który wydał zezwolenie, obowiązek przeliczenia opłaty w sytuacji, gdy:

- posadzone drzewa lub krzewy albo część z nich nie zachowały żywotności po upływie okresu, o którym mowa w art. 84 ust. 3 u.o.p. z przyczyn zależnych od posiadacza nieruchomości;

- nie wykonano nasadzeń zastępczych lub części z nich zgodnie z zezwoleniem na usunięcie drzewa lub krzewu.

W pierwszym ze wskazanych przypadków mamy do czynienia z sytuacją, gdy adresat decyzji administracyjnej wywiązał się z obowiązku dokonania nasadzeń zastępczych zgodnie $\mathrm{z}$ udzielonym zezwoleniem, jednakże posadzone drzewa lub krzewy, z przyczyn zależnych od posiadacza nieruchomości, nie zachowały żywotności. W drugim ze wskazanych przypadków

11 Zgodnie z art. 5 pkt 26e u.o.p. przez żywotność drzewa lub krzewu rozumie się prawidłowy przebieg ogółu procesów życiowych drzewa lub krzewu.

12 Z dniem 28 sierpnia 2015 r. weszła w życie Ustawa z dnia 25 czerwca 2015 r. o zmianie Ustawy o samorządzie gminnym oraz niektórych innych ustaw, Dz.U. z 2015 r., poz. 1045, nowelizująca Ustawę o ochronie przyrody. 
należy zwrócić uwagę na fakt, iż dyspozycja normy prawnej obejmuje sytuację niewykonania nasadzeń zgodnie z zezwoleniem. Oznacza to, że dotyczy ona zarówno przypadku, kiedy w ogóle nie wykonano nasadzeń zastępczych, jak i zrealizowano te nasadzenia $\mathrm{w}$ sposób niezgodny z zezwoleniem. Naruszenie warunków zezwolenia może dotyczyć nie tylko ustaleń odnoszących się do materiału nasadzeniowego (ilość, gatunek, wielkość lub wiek sadzonek), ale także sposobu dokonania nasadzeń (miejsce, termin, warunki techniczne). Należy w związku z tym przyjąć, że wykonanie nasadzeń zastępczych po upływie terminu wskazanego w zezwoleniu, w innym miejscu lub z wykorzystaniem sadzonek niespełniających wymogów zezwolenia stanowi niewykonanie nasadzeń zastępczych zgodnie z zezwoleniem, w rozumieniu art. 86 ust. 7 u.o.p., a w konsekwencji skutkować będzie obowiązkiem uiszczenia ustalonej w zezwoleniu opłaty. Przeliczenie opłaty następuje proporcjonalnie, odpowiednio do liczby drzew lub powierzchni krzewów, które nie zachowały żywotności lub do liczby drzew albo powierzchni krzewów niewykonanych zgodnie z zezwoleniem. Przeliczenia opłaty dokonuje organ właściwy do wydania zezwolenia na usunięcie drzewa lub krzewu w formie decyzji administracyjnej. Analiza zawartych w znowelizowanej Ustawie o ochronie przyrody rozwiązań prowadzi do wniosku, iż ustawodawca, w każdym przypadku wydania zezwolenia na usunięcie drzew i krzewów z jednoczesnym ustaleniem opłaty z tego tytułu oraz nałożeniem obowiązku nasadzeń zastępczych, przyjął konieczność wydania odrębnej, dodatkowej decyzji administracyjnej $\mathrm{w}$ przedmiocie ustalonej w zezwoleniu opłaty. W przypadku prawidłowego wykonania nasadzeń zastępczych oraz zachowania żywotności drzew oraz krzewów lub niezachowania żywotności z przyczyn niezależnych od posiadacza nieruchomości będzie to decyzja o umorzeniu opłaty. W momencie niewykonania obowiązku zgodnie z decyzją bądź też niezachowania żywotności drzew lub krzewów z przyczyn zależnych od posiadacza nieruchomości będzie to decyzja o przeliczeniu należnej opłaty. Decyzja umorzeniowa będzie mogła zostać wydana co do zasady dopiero po upływie okresu trzech lat od dnia wskazanego w zezwoleniu jako termin dokonania nasadzeń zastęp- 
czych. Wyjątek stanowi decyzja o umorzeniu opłaty w związku z niezachowaniem żywotności drzew lub krzewów z przyczyn niezależnych od właściciela, która może zostać wydana przed upływem okresu odroczenia. W razie decyzji przeliczeniowej organ właściwy do wydania zezwolenia może wszcząć postępowanie administracyjne oraz wydać przedmiotową decyzję przed upływem określonego w zezwoleniu terminu odroczenia opłaty. Postępowanie to może zostać wszczęte bezpośrednio po upływie wskazanego w zezwoleniu terminu dokonania nasadzeń zastępczych. Okolicznościami uzasadniającymi wszczęcie postępowania w przedmiocie przeliczenia opłaty będą w szczególności brak zawiadomienia o wykonaniu nasadzeń zastępczych lub wynik kontroli tych nasadzeń przeprowadzonej przez właściwy organ po otrzymaniu zawiadomienia o dopełnieniu obowiązku.

Nie budzi większych wątpliwości wola ustawodawcy co do możliwości zwolnienia się adresata zezwolenia na usunięcie drzew i krzewów z obowiązku opłatowego poprzez wykonanie obowiązku nasadzeń zastępczych oraz zapewnienie żywotności posadzonych drzew oraz krzewów w ustawowo określonym terminie. Wola ustawodawcy w tym zakresie została wyrażona w sposób wyraźny poprzez treść art. 84 ust. 4 u.o.p. nakazującą organowi administracji publicznej umorzenie naliczonej opłaty. Powstaje jednak pytanie, jak kształtują się określone w zezwoleniu na usunięcie drzew i krzewów obowiązki adresata decyzji w przypadku skorzystania z przyznanego uprawnienia (usunięcie drzewa lub krzewu) z jednoczesnym zaniechaniem obowiązku nasadzeń zastępczych. W szczególności nasuwa się pytanie, czy w sytuacji takiej na posiadaczu nieruchomości ciąży wyłącznie obowiązek uiszczenia naliczonej opłaty, czy też spoczywają dwa obowiązki - dokonania nasadzeń zastępczych i uiszczenia naliczonej opłaty. Analiza przepisów Ustawy o ochronie przyrody prowadzi do wniosku, iż ustawodawca nie określił expressis verbis, że na skutek uiszczenia opłaty za usunięcie drzewa lub krzewu wygasa obowiązek dokonania nasadzeń zastępczych. Przyjęcie, iż konstrukcja obowiązku nasadzeń zastępczych odpowiada koncepcji zlecenia jako elementu dodatkowego aktu administracyjnego, kreującego subsydiarny względem upraw3/2015 nienia obowiązek administracyjny, prowadzi do wniosku, iż wy- 
gaśnięcie tego obowiązku nastąpi co do zasady poprzez jego wykonanie lub w przypadkach wyraźnie określonych w przepisach prawa. Analiza przepisów Ustawy o ochronie przyrody prowadzi do wniosku, że ustawodawca nie określił w niej wprost przesłanek wygaśnięcia obowiązku dokonania nasadzeń zastępczych. Zezwolenie na usunięcie drzewa lub krzewu, w którym naliczona została opłata oraz określony został obowiązek nasadzeń zastępczych, stanowi złożony akt administracyjny, w zakresie rozstrzygnięcia którego zawiera się uprawnienie do podjęcia określonych działań, związany z tym uprawnieniem obowiązek uiszczenia opłaty oraz dokonania nasadzeń zastępczych. Brak jest jakichkolwiek podstaw wynikających wprost z przepisów prawa, dla przyjęcia jakoby obowiązki te ukształtowane były względem siebie alternatywnie. Przyjęcie przez ustawodawcę modelu obligatoryjnego umorzenia opłaty w sytuacji zgodnego z prawem wykonania obowiązku nasadzeń zastępczych stanowi jedynie wyraz preferencji ustawodawcy na sposób kompensowania uszczerbku środowiskowego spowodowanego usunięciem drzewa lub krzewu. Ustawodawca daje w ten sposób wyraz gotowości rezygnacji ze środków finansowo-prawnych na rzecz dobrowolnego i zgodnego z treścią zezwolenia kompensowania szkód in natura. Rozwiązanie to ma pełnić przede wszystkim funkcję stymulującą opartą o bodźce pozytywne, oddziaływujące na zachowanie adresata aktu administracyjnego. Ta swoistego rodzaju „zachęta” prawna wzmacniająca motywację podmiotu administrowanego do podejmowania zachowań zgodnych $\mathrm{z}$ prawem ustaje $\mathrm{w}$ momencie niedopełnienia przez posiadacza nieruchomości nasadzeń zastępczych i przy jednoczesnym upływie terminu ich dokonania. Obowiązkiem organu administracji publicznej jest $\mathrm{w}$ takim przypadku, zgodnie $\mathrm{z}$ art. 84 ust. 7 u.o.p., przeliczenie należnej opłaty oraz podjęcie działań zmierzających do przymusowego wykonania obowiązku nasadzeń zastępczych. Należy jeszcze raz wyraźnie podkreślić, iż obowiązek nasadzeń zastępczych jest typowym obowiązkiem administracyjnym wynikającym z decyzji administracyjnej, do którego odnoszą się wszelkie zasady prawa i postępowania administracyjnego związane z wykonalnością aktu administracyjnego. 


\section{NIEDOPEENIENIE OBOWIĄZKU NASADZEŃ ZASTĘPCZYCH W PRZYPADKU ZWOLNIENIA Z OPŁATY ZA USUNIĘCIE DRZEW I KRZEWÓW}

Kompensacyjny charakter zarówno opłaty za usunięcie drzew oraz krzewów, jak i obowiązku nasadzeń zastępczych stanowił źródło wątpliwości co do dopuszczalności nałożenia na posiadacza nieruchomości obowiązku nasadzeń zastępczych w sytuacji, gdy - zgodnie z art. 86 ust. 1 u.o.p. - podlegał on zwolnieniu z obowiązku uiszczenia opłaty ${ }^{13}$. Wątpliwości te, $\mathrm{w}$ mojej ocenie, zostały definitywnie usunięte $\mathrm{z}$ jednej strony poprzez określenie w art. 83c ust. 4 u.o.p. wytycznych dla organu orzekającego w zakresie obowiązku nasadzeń zastępczych, $\mathrm{z}$ drugiej poprzez regulację zawartą $\mathrm{w}$ art. 86 ust. 2 i 3 u.o.p. W wytycznych tych w sposób wyraźny wyeksponowane zostały cechy usuwanego drzewa lub krzewu (wartość przyrodnicza, w tym rozmiar drzewa lub powierzchnia krzewów oraz funkcje, jakie pełni w ekosystemie, wartość kulturowa, walory krajobrazowe, lokalizacja) jako podstawowe determinanty rozstrzygnięcia $\mathrm{w}$ przedmiocie nasadzeń zastępczych. Jednocześnie ustawodawca $\mathrm{w}$ art. 86 ust. 2 u.o.p. zastrzegł, iż w przypadkach objętych ustawowym zwolnieniem z obowiązku uiszczenia opłaty, jeżeli wydanie zezwolenia na usunięcie drzewa lub krzewu zostało uzależnione od wykonania nasadzeń zastępczych, a posadzone drzewo lub krzew nie zachowały żywotności po 3 latach od dnia upływu terminu wskazanego w tym zezwoleniu na wykonanie nasadzeń zastępczych lub przed upływem tego okresu, z przyczyn zależnych od posiadacza nieruchomości organ właściwy do wydania zezwolenia na usunięcie drzewa lub krzewu nakłada ponownie w drodze decyzji obowiązek wykonania nasadzeń zastępczych. Przepis ten odnosi się więc do sytuacji, w której podmiot zobowiązany dokonał nasadzeń zastępczych, w wyniku czego obowiązek nałożony zezwoleniem na usunięcie drzewa lub krzewu wygasł, jednakże po upływie ustawowo określonego terminu posadzone drzewa lub krzewy

13 K. Gruszecki, Realizacja..., s. 40. 
nie zachowały żywotności. W takiej sytuacji ustawodawca upoważnia organ administracji publicznej do ponownego nałożenia obowiązku nasadzeń zastępczych. Należy przyjąć, iż obowiązek ten zostanie nałożony odrębną decyzją administracyjną, z odpowiednim zastosowaniem przepisów art. 83c ust. 4 u.o.p. oraz art. 83d ust. 2 i 4 u.o.p. W art. 86 ust. 3 u.o.p. ustawodawca expressis verbis przyjął, że w sytuacji niewykonania nasadzeń zastępczych, o których mowa w art. 86 ust. 2 u.o.p., zgodnie z zezwoleniem na usunięcie drzewa lub krzewu, stosuje się przepisy o postępowaniu egzekucyjnym w administracji. Redakcja tego przepisu może jednak wzbudzać kontrowersje. Odwołanie się przez ustawodawcę do obowiązku nasadzeń zastępczych, o których mowa w art. 86 ust. 2 u.o.p. wskazuje, iż norma ta dotyczy ponownego obowiązku nasadzeń zastępczych, wynikającego z niezachowania żywotności posadzonych drzew lub krzewów. Jednocześnie ustawodawca odnosi brak wykonania tego obowiązku do treści zezwolenia na usunięcie drzew lub krzewów, co wskazuje na pierwotny obowiązek nasadzeń zastępczych określony w tym zezwoleniu. Z punktu widzenia wykładni systemowej przepis ten jest w ogóle zbędny, gdyż obowiązek nasadzeń zastępczych jako niepieniężny obowiązek administracyjny, pozostający $\mathrm{w}$ zakresie właściwości organów samorządu terytorialnego, co do zasady podlega egzekucji administracyjnej ${ }^{14}$. Przepis ten ma więc przede wszystkim funkcję porządkującą, w sposób wyraźny przesądzając o obowiązku organów administracji publicznej doprowadzenia do wykonania, wynikających z wydanych decyzji administracyjnych, obowiązków nasadzeń zastępczych. Tak wyraźna wypowiedź ustawodawcy jest szczególnie istotna $\mathrm{w}$ przypadku daleko idącej rozbieżności poglądów doktryny w sprawie skutków niedopełnienia obowiązku nasadzeń zastępczych. W obowiązującym stanie prawnym nie powinno budzić wątpliwości, że niedopełnienie obowiązku nasadzeń zastępczych obliguje organy administracji publicznej

14 Art. 2 § 1 pkt 10 Ustawy z dnia 17 czerwca 1966 r. o postępowaniu egzekucyjnym w administracji, t.j. Dz.U. z 2014 r., poz. 1619 ze zm., zwana dalej Ustawą o postępowaniu egzekucyjnym w administracji lub określana skrótem u.p.e.a. 
do podjęcia działań zmierzających do przymusowego wykonania tego obowiązku. Nie ma ono natomiast wpływu na skuteczność czy obowiązywanie samego zezwolenia na usunięcie drzew i krzewów, co potwierdza tezę, iż obowiązek nasadzeń zastępczych stanowi zlecenie, a nie warunek zezwolenia. Należy w związku z tym przyjąć, że w sytuacji niedopełnienia przez adresata zezwolenia na usunięcie drzew i krzewów obowiązku nasadzeń zastępczych (przez które należy rozumieć niedopełnienie tych obowiązków zgodnie z wydaną decyzją administracyjną) obowiązkiem organów administracji publicznej jest doprowadzenie do jego przymusowego wykonania, poprzez przewidziany w Ustawie o postępowaniu egzekucyjnym $\mathrm{w}$ administracji - system środków prawnych. W momencie dopełnienia obowiązku nasadzeń zastępczych, lecz niezachowania przez posadzone drzewa lub krzewy żywotności przez okres wskazany $\mathrm{w}$ przepisach prawa organowi administracji publicznej przysługuje kompetencja do ponownego nałożenia obowiązku dokonania nasadzeń zastępczych. Obowiązek ten objęty będzie również reżimem przymusu administracyjnego.

\section{EGZEKUCJA OBOWIĄZKU NASADZEŃ ZASTĘPCZYCH}

Jedną z gwarancji skuteczności prawa administracyjnego jest zabezpieczenie jego realizacji poprzez system środków przymusu państwowego ${ }^{15}$, szczególną postacią którego jest przymus egzekucyjny ${ }^{16}$. Egzekucja obowiązków administracyjnych podlega wyjątkowemu reżimowi prawnemu wynikającemu z Ustawy o postępowaniu egzekucyjnym $\mathrm{w}$ administracji. Zgodnie z art. 2 § 1 pkt 10 u.p.e.a. egzekucji administracyjnej podlegają

15 Na temat przymusu administracyjnego zob. J. Radwanowicz, Istota i znaczenie przymusu administracyjnego, w: Koncepcja systemu prawa administracyjnego, red. J. Zimmermann, Warszawa 2007, s. 131 i n.

16 Por. Z. Janku, Gwarancje prawne wykonania obowiązków publicznoprawnych, w: Koncepcja systemu prawa administracyjnego, red. J. Zimmermann, Warszawa 2007, s. 557 i n. 
obowiązki o charakterze niepieniężnym, pozostające we właściwości organów administracji rządowej i samorządu terytorialnego lub przekazane do egzekucji administracyjnej na podstawie przepisu szczególnego. Oznacza to, że egzekucji administracyjnej poddane zostały dwie kategorie obowiązków niepieniężnych. Pierwszą z nich stanowią obowiązki niepieniężne pozostające we właściwości organów administracji rządowej i samorządu terytorialnego, do drugiej - przekazane do egzekucji administracyjnej na podstawie przepisu szczególnego. Nie powinno budzić wątpliwości, iż obowiązek nasadzeń zastępczych jest obowiązkiem niepieniężnym pozostającym we właściwości organów samorządu terytorialnego (wójt, burmistrz, prezydent miasta). Jednocześnie ustawodawca $\mathrm{w}$ art. 86 ust. 3 u.o.p. w sposób jednoznaczny odesłał do stosowania przepisów o postępowaniu egzekucyjnym w administracji w zakresie przymusowego wykonania tego obowiązku, co należy uznać za błąd legislacyjny ${ }^{17}$. Jedną z podstawowych zasad postępowania egzekucyjnego $\mathrm{w}$ administracji jest zasada obowiązku prowadzenia egzekucji administracyjnej wyrażona $\mathrm{w}$ art. 6 $\S 1$ u.p.e.a. Zgodnie z tym przepisem $\mathrm{w}$ razie uchylania się zobowiązanego od wykonania obowiązku wierzyciel powinien podjąć czynności zmierzające do zastosowania środków egzekucyjnych. Jak zauważył NSA, uchylanie się zobowiązanego od wykonania obowiązku, o którym mowa w art. $6 \S 1$ u.p.e.a., jest nie tylko przesłanką materialnoprawną zastosowania środków egzekucyjnych, ale i przesłanką podjęcia czynności zmierzających do ich zastosowania ${ }^{18}$. Zawarty w art. $6 \S 1$ u.p.e.a. zwrot „powinien” oznacza „ma obowiązek”, a „uchylanie się od wykonania obowiązku" to niepodjęcie przez zobowiązanego działań

17 Słusznie zauważa D. Kijowski, iż błędem jest przekazywanie obowiązków do egzekucji administracyjnej na mocy przepisu szczególnego, gdy obowiązki te podlegają egzekucji $\mathrm{z}$ racji pozostawania $\mathrm{w}$ zakresie właściwości organów administracji rządowej lub samorządu terytorialnego. D. R. Kijowski, w: Ustawa o postępowaniu egzekucyjnym $w$ administracji. Komentarz, red. D. R. Kijowski, Warszawa 2015, wer.el./LEX.

18 Wyrok NSA z dnia 10 czerwca 2014 r., II FSK 1705/12, CBOSA. 
zmierzających do jego wykonania ${ }^{19}$. Jednocześnie Naczelny Sąd Administracyjny wskazuje, iż tylko wówczas, gdy zobowiązany świadomie zmierza do niewykonania ciążącego na nim obowiązku podlegającego egzekucji administracyjnej, można przypisać mu uchylanie się od jego wykonania w rozumieniu art. 6 $\S 1$ u.p.e.a. ${ }^{20}$ Przenosząc powyższe ustalenia na grunt Ustawy o ochronie przyrody, należy przyjąć, iż w każdym przypadku uchylania się podmiotu zobowiązanego od wykonania obowiązku nasadzeń zastępczych wierzyciel powinien podjąć środki prawne zmierzające do jego przymusowego wykonania. Podstawą faktyczną podjęcia tych działań będzie w szczególności ustalenie, że - pomimo upływu wskazanego w zezwoleniu terminu dokonania nasadzeń zastępczych - nasadzenia te nie zostały dokonane. Zgodnie z art. $5 \S 1$ u.p.e.a. uprawnionym do żądania wykonania $\mathrm{w}$ drodze egzekucji administracyjnej obowiązków określonych w art. 2 u.p.e.a. jest, w odniesieniu do obowiązków wynikających $\mathrm{z}$ decyzji lub postanowień organów administracji rządowej i organów jednostek samorządu terytorialnego, właściwy do orzekania organ I instancji. W myśl tej zasady wierzycielem obowiązku dokonania nasadzeń zastępczych jest wójt (burmistrz, prezydent miasta), który wydał zezwolenie na usunięcie drzewa lub krzewu, a - w przypadku ponownego obowiązku nasadzeń zastępczych - wójt (burmistrz, prezydent miasta), który wystawił decyzję nakładającą ten obowiązek. Organ ten będzie jednocześnie, zgodnie z art. $20 \S 1$ pkt 2, w związku z art. 1a pkt 14 u.p.e.a., organem egzekucyjnym. Czynnościami zmierzającymi do zastosowania środków egzekucyjnych są w szczególności: skierowanie do zobowiązanego upomnienia, wystawienie tytułu wykonawczego oraz złożenie wniosku do organu egzekucyjnego o wszczęcie postępowania egzekucyjnego, a w sytuacji tożsamości podmiotowej wierzyciela i organu egzekucyjnego wszczęcie postępowania egzekucyjnego. Stosowanie środków egzekucyjnych, rozumianych jako zinstytucjonalizowane formy przymusu państwowego służące

19 Wyrok NSA z dnia 19 listopada 2010 r., II FSK 1957/10, CBOSA; Wyrok WSA w Gliwicach z dnia 29 maja 2013 r., I SA/Gl 146/14, CBOSA.

20 Wyrok NSA z dnia 10 czerwca 2014 r., II FSK 1705/12, CBOSA. 
doprowadzeniu do wykonania przez zobowiązanego obowiązków wynikających ze stosunków administracyjnoprawnych oraz innych obowiązków poddanych egzekucji administracyjnej ${ }^{21}$, odbywa się w oparciu o ściśle określone zasady, do których należy w szczególności zasada stosowania środków przewidzianych w ustawie, zasada celowości, zasada stosowania najmniej uciążliwego środka, zasada bezpośredniości i zasada niezbędności. Zasady te można by ująć wspólnie regułą, zgodnie z którą organ egzekucyjny ma obowiązek prowadzenia egzekucji administracyjnej poprzez zastosowanie środka egzekucyjnego przewidzianego Ustawą o postępowaniu egzekucyjnym w administracji, który - będąc najmniej dolegliwym środkiem dla zobowiązanego - doprowadzi bezpośrednio do wykonania obowiązku poddanego egzekucji. Ustawowo określonymi środkami egzekucyjnymi adekwatnymi do egzekucji obowiązku nasadzeń zastępczych jest grzywna w celu przymuszenia oraz wykonanie zastępcze. Grzywna w celu przymuszenia stanowi tzw. przymuszający środek egzekucyjny, który ze względu na dolegliwość natury finansowej, skłania zobowiązanego do wykonania obowiązku administracyjnego ${ }^{22}$. Przepisy Ustawy o postępowaniu egzekucyjnym w administracji wskazują, iż każdorazowo nałożona grzywna nie może przekraczać kwoty 10000 zł, a w stosunku do osób prawnych i jednostek organizacyjnych nieposiadających osobowości prawnej kwoty 50000 zł. W przypadku dalszego uchylania się zobowiązanego od wykonania obowiązku grzywna w celu przymuszenia może być nakładana kilkakrotnie w tej samej lub wyższej kwocie. Grzywny nakładane wielokrotnie nie mogą łącznie przekroczyć kwoty 50000 zł, a w stosunku do osób prawnych i jednostek organizacyjnych nieposiadających osobowości prawnej kwoty 200000 zł. Organ egzekucyjny, dokonując konkretyzacji środka egzekucyjnego poprzez

21 E. Bojanowski, Wykonanie zastępcze $w$ egzekucji administracyjnej, Warszawa 1975, s. 35.

22 Por. I. Skrzydło-Niżnik, Grzywna w celu przymuszenia w egzekucji administracyjnej, w: System egzekucji administracyjnej, red. J. Niczyporuk, S. Fundowicz, J. Radwanowicz, Warszawa 2004, s. 451 i n.; Wyrok NSA z dnia 10 maja 2012 r., II OSK 312/11 i z dnia 26 lipca 2012 r., II OSK 813/11, CBOSA. 
ustalenie wartości nakładanej grzywny w celu przymuszenia, działa w granicach uznania administracyjnego. Ustalenie wysokości grzywny w celu przymuszenia jest determinowane przede wszystkim zasadą celowości i skuteczności podejmowanych działań. Grzywna w celu przymuszenia pełni przede wszystkim funkcję stymulującą i dyscyplinującą, musi stanowić na tyle silny bodziec finansowy, który skłoni zobowiązanego do oczekiwanego przez administrację zachowania. Nałożona grzywna powinna być na tyle wysoka, aby w ocenie zobowiązanego nieopłacalnym było jej uiszczenie tylko dla odłożenia w czasie egzekwowanego obowiązku, czy to poprzez osobiste wykonanie przez zobowiązanego, czy w drodze wykonania zastępczego ${ }^{23}$. W ocenie NSA wysokość grzywny w celu przymuszenia należy także uzależniać od sytuacji majątkowej zobowiązanego, gdyż skuteczność kary egzekucyjnej wynika także z jej dolegliwości, a dostateczna dolegliwość grzywny ma stanowić bodziec do wykonania obowiązku podlegającego egzekucji ${ }^{24}$. Jednocześnie NSA wyklucza konieczność uwzględnienia możliwości finansowych zobowiązanego wynikających z jego złej sytuacji majątkowej i dochodowej, gdyż zobowiązany „niezależnie od majętności, może bowiem uwolnić się od konieczności uiszczenia grzywny poprzez wykonanie ciążącego na nim obowiązku"25. Grzywna w celu przymuszenia nie jest sankcją karną. Jej istotą nie jest ukaranie zobowiązanego za uchylanie się od wypełnienia ciążącego na nim obowiązku dokonania nasadzeń zastępczych, lecz wywarcie presji finansowej, stworzenie swoistego stanu „nieopłacalności”, w ekonomicznym znaczeniu, dalszego uchylania się od obowiązków administracyjnych. W doktrynie prawa administracyjnego wskazuje się, iż kara administracyjna jest przede wszystkim odpłatą za nieposłuszeństwo w sytuacji, gdy egzekucja ma na celu przymusowe wprowadzenie w życie tego stanu faktycznego, który został przewidziany przez nor-

23 Por. Wyrok WSA w Łodzi z dnia 8 maja 2014 r., II SA/Łd 66/14 oraz Wyrok WSA w Gdańsku z dnia 28 marca 2012 r., II SA/Gd 36/12, CBOSA.

25 Wyrok NSA z dnia 15 października 2014 r., I OSK 1466/14, CBOSA. 
mę ${ }^{26}$. Celem grzywny egzekucyjnej nie jest represja za niezgodne z prawem zachowanie się, ale złamanie oporu zobowiązanego, czyli przymuszenie do wykonania obowiązku ${ }^{27}$. W związku z powyższym w przypadku wykonania obowiązku określonego w tytule wykonawczym nałożone, a nieuiszczone lub nieściągnięte grzywny w celu przymuszenia podlegają umorzeniu. Umorzenie to ma charakter obligatoryjny i dokonywane jest na wniosek zobowiązanego, w drodze postanowienia wydawanego przez organ egzekucyjny. Również uiszczone lub ściągnięte grzywny mogą być, na wniosek zobowiązanego, zwrócone w wysokości 75\% lub w całości, ale wyłącznie w uzasadnionych przypadkach.

Wykonanie zastępcze jest drugim, obok grzywny w celu przymuszenia, środkiem egzekucyjnym służącym wyegzekwowaniu niepieniężnych obowiązków administracyjnych polegających na wykonaniu określonej czynności. W momencie obowiązku nasadzeń zastępczych środek ten znajdzie zdecydowanie węższy zakres zastosowania, jakkolwiek brak jest podstaw do całkowitego wykluczenia jego stosowania przy egzekwowaniu przedmiotowego obowiązku. Wykonanie zastępcze stanowi środek egzekucyjny zaspokajający, czyli taki, którego podjęcie prowadzi bezpośrednio do wykonania egzekwowanego obowiązku. Istotą wykonania zastępczego jest zlecenie wykonania obowiązku ciążącego na zobowiązanym innemu wykonawcy na koszt zobowiązanego. Środek ten może zostać zastosowany więc wyłącznie do obowiązków niewymagających osobistego działania zobowiązanego, a takim obowiązkiem jest niewątpliwie obowiązek nasadzeń zastępczych. Przedmiotem wykonania zastępczego może być wyłącznie obowiązek wskazany w tytule wykonawczym, którego treść musi ściśle odpowiadać jego podstawie materialnoprawnej, którą w przypadku nasadzeń zastępczych jest zezwolenie na usunięcie drzewa lub krzewu. Oznacza to ko-

26 A. Peretiatkowicz, Podstawowe pojęcia prawa administracyjnego, Poznań 1946, s. 44.

${ }^{27}$ J. Jendrośka, Kary administracyjne, w: Księga jubileuszowa Profesora Marak Mazurkiewicza. Studia z dziedziny prawa finansowego, prawa konstytucyjnego i ochrony środowiska, Wrocław 2001, s. 55. 
nieczność wykonania obowiązku zgodnie z treścią zezwolenia, a więc zarówno $\mathrm{w}$ miejscu wskazanym $\mathrm{w}$ tym zezwoleniu, jak i z wykorzystaniem określonego tam materiału nasadzeniowego (ilość, gatunek, wielkość, wiek), a w przypadku określenia w zezwoleniu również warunków technicznych posadzenia drzewa, zgodnie z tymi warunkami.

\section{ZAKRES STOSOWANIA ART. $162 \S 2$ K.P.A. DO OBOWIĄZKU NASADZEŃ ZASTĘPCZYCH}

W myśl art. $162 \S 2$ k.p.a. organ administracji publicznej, który wydał decyzję w I instancji, uchyli tę decyzję, jeżeli została ona wydana z zastrzeżeniem dopełnienia określonych czynności, a strona nie dopełniła tych czynności w wyznaczonym terminie. Przepis ten stanowi podstawę nadzwyczajnego trybu wyeliminowania z obrotu prawnego ostatecznej, niewadliwej decyzji administracyjnej i jako taki stanowi wyjątek od zasady trwałości aktów administracyjnych. W doktrynie prawa administracyjnego wskazuje się, iż z wykładni językowej przepisu art. $162 \S 2$ k.p.a. wynika, że organ administracji publicznej jest obowiązany uchylić decyzję, w której: a) nałożono na stronę obowiązek dopełnienia określonych czynności; b) wyznaczono termin dokonania tych czynności, a strona nie dopełniła tych czynności w wyznaczonym terminie ${ }^{28}$. Decyzja uchylająca decyzję obarczoną zleceniem ma charakter konstytuwny, wywołuje ona skutki ex nunc ${ }^{29}$, tzn. od dnia, w którym stanie się ostateczna. Oznacza to, że decyzja uchylająca nie niweczy skutków prawnych decyzji uchylanej powstałych w okresie jej obowiązywania, a wszelkie czynności podjęte na jej podstawie i zgodnie

28 A. Wróbel, Komentarz aktualizowany do art. 162 kodeksu postępowania administracyjnego, LEX/el. 2015.

29 Por. T. Woś, Stwierdzenie wygaśnięcia decyzji administracyjnej jako bezprzedmiotowej (art. 162 k.p.a.), „Państwo i Prawo” 1992, nr 7, s. 50; Idem, Termin, warunek i zlecenie w prawie administracyjnym, „Państwo i Prawo” 1994, nr 6, s. 34. 
z jej treścią zachowują przymiot legalności. Odnosząc powyższe ustalenia do instytucji nasadzeń zastępczych, należy stwierdzić, iż ewentualne uchylenie zezwolenia na usunięcie drzewa lub krzewu, gdzie został zastrzeżony obowiązek nasadzeń zastępczych, na podstawie art. $162 \S 2$ k.p.a., w sytuacji gdy adresat zezwolenia skorzystał z przyznanego mu uprawnienia i jednocześnie nie wywiązał się z obowiązku dokonania nasadzeń zastępczych, nie wywoła skutku w postaci delegalizacji czynności usunięcia drzewa lub krzewu, a jedynie zwolni adresata decyzji z obowiązku nasadzeń zastępczych, co należy uznać za działanie contra legem. Sytuacja mogłaby być jeszcze bardziej kuriozalna w przypadku zezwolenia na odpłatne usunięcie drzewa lub krzewu z jednoczesnym nałożeniem obowiązku nasadzeń zastępczych, gdyż wówczas niedopełnienie obowiązku nasadzeń zastępczych, skutkujące uchyleniem zezwolenia, uwolniłoby również adresata decyzji od obowiązku poniesienia opłaty, która zgodnie z art. 84 ust. 4 u.o.p. została odroczona. Z samej więc już istoty rozwiązań przyjętych na gruncie Ustawy o ochronie przyrody wypływa wniosek o konieczności odrzucenia możliwości stosowania art. $162 \S 2$ k.p.a. w zakresie zezwoleń na usunięcie drzewa lub krzewu zobowiązujących do dokonania nasadzeń zastępczych. Brak możliwości zastosowania art. 162 $\S 2$ k.p.a. do zezwoleń na usunięcie drzewa lub krzewu wynika jednak również bezpośrednio z konstrukcji tego przepisu. Dyspozycja normy prawnej zawartej w art. $162 \S 2$ k.p.a. odnosi się do decyzji wydanej z zastrzeżeniem dopełnienia określonej czynności. W analizowanym przepisie pojęcie decyzji użyte zostało $\mathrm{w}$ znaczeniu materialnoprawnym, przez które rozumiem władcze oświadczenie woli organu administracji publicznej określające konsekwencje stosowanej normy prawnej w odniesieniu do konkretnie oznaczonego adresata $\mathrm{w}$ sprawie indywidualnej. W związku z powyższym należy zastanowić się które władcze oświadczenie woli organu administracji publicznej, zawarte w zezwoleniu na usunięcie drzewa lub krzewu, w znaczeniu formalnym zostało złożone z zastrzeżeniem dopełnienia określonej czynności. Oświadczeniem tym jest niewątpliwie oświadczenie zezwalające na usunięcie drzewa lub krzewu. Zgodnie $\mathrm{z}$ art. 83c ust. 3 u.o.p. wydanie zezwolenia na usunię- 
cie drzewa lub krzewu może być uzależnione od określonych przez organ nasadzeń zastępczych lub przesadzenia tego drzewa lub krzewu. Oznacza to, że decyzją, o której mowa w art. $162 \S 2$ k.p.a., jest wyłącznie władcze oświadczenie organu administracji publicznej zezwalające na usunięcie konkretnie oznaczonego drzewa lub krzewu, gdyż to ono zostało złożone z zastrzeżeniem dopełnienia określonej czynności, w tym przypadku nasadzeń zastępczych. Oświadczenie to wywołuje skutki prawne w postaci uprawnienia przysługującego adresatowi decyzji administracyjnej. $\mathrm{Z}$ istoty zezwolenia na usunięcie drzewa lub krzewu wynika, iż uprawnienie to odnosi się do podjęcia jednorazowej czynności. Skorzystanie z przyznanego uprawnienia (usunięcie drzewa lub krzewu) powoduje wygaśnięcie decyzji w ujęciu materialnym w części dotyczącej rozstrzygnięcia uprawniającego do podjęcia określonych czynności ${ }^{30}$. Jeżeli decyzja, która została wydana z zastrzeżeniem dopełnienia określonej czynności, wygasła na skutek jej wykonania, co oznacza ustanie jej bytu prawnego, to brak jest podstaw do jej uchylenia na podstawie art. $162 \S 2$ k.p.a. Nie jest bowiem dopuszczalne uchylenie decyzji, która nie istnieje $\mathrm{w}$ znaczeniu materialnoprawnym. W związku z powyższym należy stwierdzić, iż przepis art. $162 \S 2$ k.p.a. nie może być stosowany w przypadku zrealizowanego zezwolenia na usunięcie drzewa lub krzewu, pomimo braku dopełnienia obowiązku nasadzeń zastępczych. Obowiązkiem organu administracji publicznej jest bowiem doprowadzenie, przy wykorzystaniu przysługujących mu środków prawnych, w tym środków przymusu, do wykonania obowiązku nasadzeń zastępczych, o czym expressis verbis stanowi art. 86 ust. 3 u.o.p. 


\section{WNIOSKI KOŃCOWE}

Nasadzenia zastępcze stanowią istotny element administracyjnoprawnego modelu powszechnej ochrony przyrody, wpisując się w ogólną zasadę zrównoważonego rozwoju oraz zasadę sektorową zrównoważonego gospodarowania zasobami przyrody. Odrzucenie koncepcji warunku jako formuły odpowiadającej relacji obowiązku nasadzeń zastępczych w stosunku do przyznanego zezwoleniem uprawnienia do usunięcia drzewa lub krzewu wyklucza możliwość przyjęcia bezpośredniego wpływu niedopełnienia obowiązku nasadzeń zastępczych na skuteczność zezwolenia na usunięcie drzewa lub krzewu, a co się z tym wiąże przyjęcie, iż niedopełnienie obowiązku nasadzeń powoduje wygaśnięcie tegoż zezwolenia. Zawarty w zezwoleniu na usunięcie drzewa lub krzewu obowiązek zrekompensowania uszczerbku przyrodniczego poprzez dokonanie nasadzeń zastępczych w pełni odpowiada, przyjętej na gruncie prawa administracyjnego, koncepcji zlecenia. Wykreowany, poprzez zastrzeżenie zawarte $\mathrm{w}$ akcie przyznającym uprawnienie, obowiązek stanowi w swej istocie odrębny akt administracyjny ${ }^{31}$ (w ujęciu materialnym), którego wykonanie podlega ogólnemu reżimowi prawa administracyjnego. Przyjęcie przez ustawodawcę rozwiązania polegającego na umorzeniu opłaty za usunięcie drzewa lub krzewu w przypadku zgodnego z prawem wykonania obowiązku nasadzeń zastępczych pozostaje bez istotnego wpływu na byt prawny samego obowiązku nasadzeń zastępczych. W rozwiązaniu tym należy upatrywać przede wszystkim funkcji stymulującej, kreującej pozytywne zachowania adresata zezwolenia w zakresie wykonania ciążących na nim obowiązków. Dlatego też nie sposób przyjąć, że wyłącznym skutkiem niedopełnienia obowiązku nasadzeń zastępczych jest aktualizacja obowiązku opłatowego. Żaden przepis Ustawy o ochronie przyrody nie daje podstaw dla uzasadnienia tezy o wygaśnięciu obowiązku nasadzeń zastępczych na skutek uiszczenia opłaty

31 E. Ochendowski, Prawo administracyjne. Część ogólna, Toruń 2013, s. 212 . 
za usunięcie drzewa lub krzewu. Brak jest również podstaw do przyjęcia swoistej konkurencyjności obowiązku nasadzeń zastępczych i obowiązku uiszczenia opłaty skutkującej istnieniem po stronie zobowiązanego prawa wyboru realizowanego przez niego ciężaru. Dlatego też należy przyjąć, iż podstawowym skutkiem niedopełnienia, wynikającego z zezwolenia na usunięcie drzew i krzewów, obowiązku nasadzeń zastępczych jest uruchomienie kompetencji organów administracji publicznej do podjęcia przewidzianych prawem środków prawnych gwarantujących wykonanie aktu administracyjnego. Kompetencje te są źródłem nie tylko uprawnień organów administracji publicznej, ale przede wszystkim obowiązków zagwarantowania skuteczności norm prawa administracyjnego poprzez ich przymusowe wykonanie.

\section{BIBLIOGRAFIA}

Bojanowski E., Wykonanie zastępcze w egzekucji administracyjnej, Warszawa 1975.

Gruszecki K., Realizacja zasady zrównoważonego rozwoju środowiska („nasadzenia zastępcze”), ZNSA 2007, nr 5-6.

Gruszecki K., Zezwolenia na usunięcie drzew i krzewów, LEX/el 2010, Habuda A., Radecki W., Instytucje prawa ochrony przyrody, w: Instytucje prawa ochrony środowiska. Geneza-rozwój-perspektywy, red. W. Radecki, Warszawa 2010.

Janku Z., Gwarancje prawne wykonania obowiązków publicznoprawnych, w: Koncepcja systemu prawa administracyjnego, red. J. Zimmermann, Warszawa 2007.

Jendrośka J., Kary administracyjne, w: Księga jubileuszowa Profesora Marka Mazurkiewicza. Studia z dziedziny prawa finansowego, prawa konstytucyjnego i ochrony środowiska, red. R. Mastalski, Wrocław 2001.

Kijowski D. R., w: Ustawa o postępowaniu egzekucyjnym w administracji. Komentarz, red. D. R. Kijowski, Warszawa 2015.

Kijowski D. R., Uprawnienia administracyjne, w: System prawa administracyjnego, t. 7, Prawo administracyjne materialne, red. R. Hauser, Z. Niewiadomski, A. Wróbel, Warszawa 2012. 
Klimek G., Nasadzenia zastępcze - wybrane problemy w podejmowaniu decyzji, w: Prawne aspekty gospodarowania zasobami środowiska. Korzystanie z zasobów środowiska, red. B. Rakoczy, M. Szalewska, K. Karpus, Toruń 2014.

Ochendowski E., Prawo administracyjne. Część ogólna, Toruń 2013, s. 212.

Peretiatkowicz A., Podstawowe pojęcia prawa administracyjnego, Poznań 1946.

Radecki W., Nasadzenia zastępcze przy usuwaniu drzew bez konieczności ponoszenia optat, „Nowe Zeszyty Samorządowe” 2006, nr 2.

Radecki W., Rozliczanie opłat za usuwanie drzew, „Nowe Zeszyty Samorządowe" 2010, nr 1.

Radwanowicz J., Istota $i$ znaczenie przymusu administracyjnego, w: Koncepcja systemu prawa administracyjnego, red. J. Zimmermann, Warszawa 2007.

Rakoczy B., Usuwanie drzew i krzewów, Warszawa 2013.

Rotko J., w: Teoretyczne podstawy prawa ochrony przyrody, red. W. Radecki, Wrocław 2006.

Skrzydło-Niżnik I., Grzywna w celu przymuszenia w egzekucji administracyjnej, w: System egzekucji administracyjnej, red. J. Niczyporuk, S. Fundowicz, J. Radwanowicz, Warszawa 2004.

Woś T., Stwierdzenie wygaśnięcia decyzji administracyjnej jako bezprzedmiotowej (art. 162 k.p.a.), „Państwo i Prawo” 1992, nr 7.

Woś T., Termin, warunek $i$ zlecenie $w$ prawie administracyjnym, „Państwo i Prawo" 1994, nr 6.

Wróbel A., Komentarz aktualizowany do art. 162 kodeksu postępowania administracyjnego, LEX/el. 2015.

Zimmermann J., Prawo administracyjne, Warszawa 2012.

Kontakt e-mail:

szalew@law.umk.pl 